\title{
The Tibetan Plateau observatory of plateau scale soil moisture and soil temperature (Tibet-Obs) for quantifying uncertainties in coarse resolution satellite and model products
}

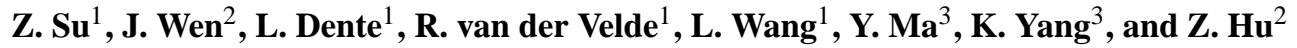 \\ ${ }^{1}$ Faculty of Geo-Information Science and Earth Observation (ITC), University of Twente, Enschede, The Netherlands \\ ${ }^{2}$ Key Laboratory of Land Surface Process and Climate Change in Cold and Arid Regions, Cold and Arid Regions \\ Environmental and Engineering Research Institute, Chinese Academy of Sciences (CAREERI/CAS), Lanzhou, China \\ ${ }^{3}$ TEL, Institute of Tibetan Plateau Research, Chinese Academy of Sciences (ITP/CAS), Beijing, China
}

Received: 22 December 2010 - Published in Hydrol. Earth Syst. Sci. Discuss.: 17 January 2011

Revised: 4 July 2011 - Accepted: 5 July 2011 - Published: 18 July 2011

\begin{abstract}
A plateau scale soil moisture and soil temperature observatory is established on the Tibetan Plateau for quantifying uncertainties in coarse resolution satellite and model products of soil moisture and soil temperature. The Tibetan Plateau observatory of plateau scale soil moisture and soil temperature (Tibet-Obs) consists of three regional scale insitu reference networks, including the Naqu network in a cold semiarid climate, the Maqu network in a cold humid climate and the Ngari network in a cold arid climate. These networks provide a representative coverage of the different climate and land surface hydrometeorological conditions on the Tibetan plateau. In this paper the details of the Tibet-Obs are reported. To demonstrate the uniqueness of the TibetObs in quantifying and explaining soil moisture uncertainties in existing coarse satellite products, an analysis is carried out to assess the reliability of several satellite products for the Naqu and the Maqu network areas. It is concluded that global coarse resolution soil moisture products are useful but exhibit till now unreported uncertainties in cold and semiarid regions - use of them would be critically enhanced if uncertainties can be quantified and reduced using in-situ measurements.
\end{abstract}

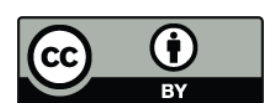

Correspondence to: $\mathrm{Z}$. Su

(z.su@utwente.nl)

\section{Introduction}

Soil moisture is a key state variable of the land surface controlling the partition of rainfall to subsoil drainage, surface runoff, or evaporation from the land surface. Understanding the dynamics of soil moisture is crucial for understanding the role of the hydrological cycle in the climate system and a variety of ecological and biogeochemical processes (Milly and Dunne, 1994; Polcher, 1995; Balsamo et al., 2008; de Rosnay et al., 2008; Drusch et al., 2008). With increasing evidence of climate change, it becomes more urgent to quantify the role of soil moisture in climate because the response of the hydrological cycle to global warming is expected to be far reaching (Bengtsson, 2010).

Quantification of trends and variability in global soil moisture can contribute to a better understanding of the feedback between the water cycle and climate. Although the soil moisture dynamics at local scale can be measured with a certain degree of confidence, it is challenging to translate this point information to a larger spatial scale due to the lack of understanding of soil moisture variability within natural landscapes. Models designed to simulate local dynamics using optimised parameters usually fail to achieve this task. Indeed, it is confirmed within the GEWEX (Global Energy and Water Cycle Experiment) Global Soil Moisture Project (Dirmeyer et al., 2004) that global models display a large, and often unexplained, variation among estimates produced by different models.

Published by Copernicus Publications on behalf of the European Geosciences Union. 
Satellite remote sensing can be a powerful tool in fulfilling the need for a consistent global soil moisture data set because it allows monitoring the land surface at the relevant spatial and temporal scales. Recent progresses have already made available several global and continental scale soil moisture datasets from satellite observations not primarily designed for this purpose (e.g. Jackson et al., 1999; Wagner et al., 2003; Njoku et al., 2003; Owe et al., 2008). The European Space Agency (ESA) operates currently a satellite, the Soil Moisture and Ocean Salinity (SMOS) (Kerr et al., 2001) mission, dedicated to global soil moisture monitoring and also the National Aeronautic and Space Administration (NASA) is in preparation of a similar soil moisture mission, Soil Moisture Active/Passive (SMAP), (Entekhabi et al., 2010). It is expected that both missions will provide improved global soil moisture products. Another promising method of obtaining consistent global soil moisture data sets is through land data assimilation (e.g. Yang et al., 2007, 2009; Drusch et al., 2008; Qin et al., 2009; Tian et al., 2009), in which continuous data sets are produced by integrating remote sensing data sets in a land surface model. At present, several such systems produce operational spatiotemporally continuous soil moisture estimates and examples are the Global Land Data Assimilation System (GLDAS) (Rodell et al., 2004) and the European Centre for Medium-Range Weather Forecasts (ECMWF) interim reanalysis (ERA-Interim) (http: //www.ecmwf.int/research/era/do/get/era-interim). Obtained either through remote sensing or land data assimilation, ideally each global soil moisture product is validated against measurements collected at a variety of sites. Throughout the globe a number of intensive soil moisture networks have been developed for various purposes, e.g. those listed in the International Soil Moisture Network (http://www.ipf.tuwien.ac. at/insitu/index.php/in-situ-networks.html). As a contribution to these monitoring programs worldwide, this paper reports on the development of an observatory in one of the most remote and least explored areas on earth, but yet very important for understanding the climate system, the Tibetan Plateau.

The Tibetan observatory includes three regional networks equipped with both soil moisture and temperature instrumentation installed across the Tibetan Plateau. The data sets collected (and to be collected) by these networks are not only expected to contribute a further insight in the role of the Tibetan Plateau in the development of the Asian Monsoon. They may also be found useful in validating satellite based soil moisture products and obtaining an improved understanding of the land surface processes in high elevation regions. In this paper, the Tibetan soil moisture and soil temperature observatory is presented in Sect. 2. Section 3 briefly describes the evaluated coarse satellite soil moisture products. The uniqueness in quantifying soil moisture uncertainties in existing coarse satellite products, by using the collected data, is demonstrated in Sect. 4 and we conclude with suggestions for future research in Sect. 5.

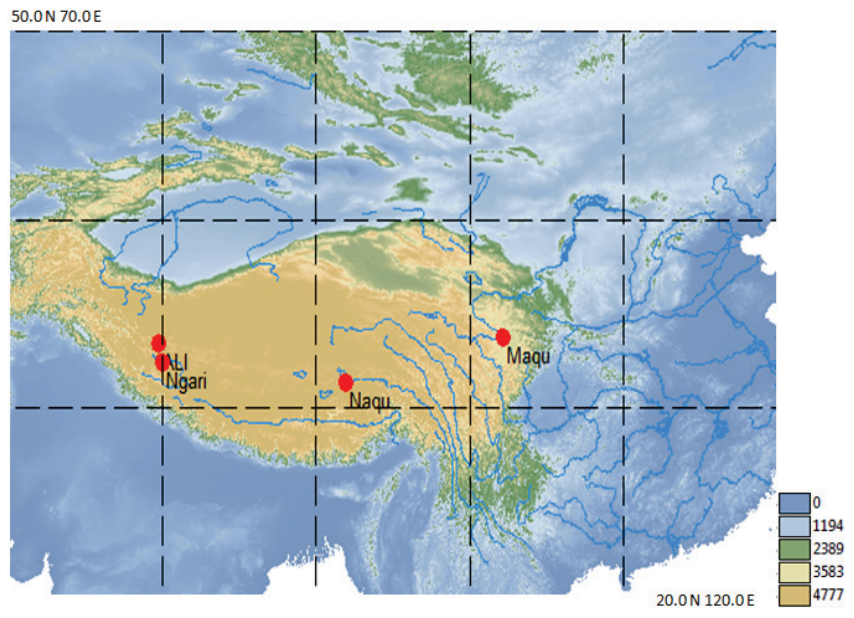

Fig. 1. Location of the three regional networks of the Tibetan Plateau soil moisture and soil temperature Observatory (Tibet-Obs). The legend indicates the altitude above mean sea level in meters.

\section{In-situ soil moisture and soil temperature networks}

The Tibetan Plateau observatory of plateau scale soil moisture and soil temperature (Tibet-Obs) consists of three regional scale in-situ reference networks (Fig. 1), including the Naqu network in a cold semiarid climate, the Maqu network in a cold humid climate and the Ngari network in a cold arid climate. These networks provide a representative coverage of the different climate and land surface hydrometeorological conditions on the Tibetan plateau. More specific information for each network is described in the following subsections.

\subsection{The Naqu network in a cold semiarid environment}

The Naqu study area is located in the Naqu basin in a flat terrain with rolling hills at an average elevation of $4500 \mathrm{~m}$ above mean sea level. Characteristic for the study area are soils with a high saturated hydraulic conductivity positioned on top of an impermeable rock formation (or permafrost layer). Rain falling on the surface runs off rapidly and accumulates in local depressions forming lakes and wetlands. The land cover in the higher parts of the study area can be characterized as grasslands consisting of prairie grasses and mosses (van der Velde et al., 2008; van der Velde and Su, 2009; van der Velde, 2010). In the winter period, very little precipitation occurs either in liquid or frozen state as snow resulting in spatially and temporally stable soil moisture dynamics in a frozen soil. In the monsoon season from May to October, the area receives its bulk precipitation with peak intensity of more than three quarters of a total annual amount of $400 \mathrm{~mm}$ from June to August. The grasslands and wetlands, coevolving with local topography and soils under the forcing of monsoon precipitation and strong radiation and winds (thus having high evaporation), form a landscape of high spatial soil moisture variability and temporal dynamics 
within spatial scales of several kilometres. In the grasslands, soil moisture conditions are determined by antecedent rainfall and evaporation and may vary from residual soil moisture to saturated contents. In the wetlands the soil moisture increases towards saturation at the onset of the monsoon because of accumulation of the thawing of frozen soil water and remain relatively stable near saturation due to runoff water supply from upstream areas.

The Naqu soil moisture and soil temperature network was installed around the Naqu Station for the Plateau Climate and Environment Observation and Research of Chinese Academy of Sciences located about $25 \mathrm{~km}$ southwest of Naqu city. This station is one of the key micrometeorological stations within a meso-scale network installed as a part of the GEWEX supported field campaigns (Ma et al., 2003, 2006, 2007). Continuous measurements are made of water and energy exchanges between the land surface and atmosphere at this station, including atmospheric variables at different heights (e.g. wind speed, humidity and temperature), incoming and outgoing (shortwave and longwave) radiation, turbulent heat fluxes, soil moisture at depths of 0.05 and $0.20 \mathrm{~m}$ below surface, and soil temperatures profile down to a depth of 0.40 m below surface (e.g. Ma et al. 2003, 2006, 2007; van der Velde et al., 2009).

To monitor the regional soil moisture dynamics and validate soil moisture retrievals from satellite data, five additional soil moisture stations were installed in June 2006. The soil moisture stations were placed north, south, west and east within $10 \mathrm{~km}$ from Naqu station with one additional one installed at Naqu station itself for comparison purpose with the existing instrumentation (Table 1). Grasslands dominate the land cover at the north, west, east and Naqu stations and south station is located in a wetland.

The instrumentation used for this network consists of EM5b data loggers and $0.10 \mathrm{~m}$ long $\mathrm{ECH}_{2} \mathrm{O}$ (type: EC-10) impedance probes both manufactured by Decagon Devices. At each station, probes have been installed horizontally at depths of 2.5, 7.5, 15.0, 30.0 and $60.0 \mathrm{~cm}$ below surface. The EM5b loggers take a measurement every minute, which are averaged to values at preset intervals. On eight days in the period 16-27 July 2006, soil samples were taken near each station to determine the soil moisture content gravimetrically and the loggers recorded readings every $30 \mathrm{~min}$ for calibration purpose. A well-defined linear relationship was reported between gravimetrically determined and impedance probe soil moisture resulting in a root mean square difference (RMSD) of $0.029 \mathrm{~m}^{3} \mathrm{~m}^{-3}$ (Van der Velde, 2010). In the period from June 2006 to October 2007 the routine recording was set at every $12 \mathrm{~h}$, while afterwards it was set at every $3 \mathrm{~h}$ and increased to $15 \mathrm{~min}$ after October 2008.

It is worth noting that this soil moisture network was greatly enhanced in July 2010. Additional 39 stations were established within a $100 \mathrm{~km}$ by $100 \mathrm{~km}$ area of this region, with each station consisting of four sets of soil moisture and soil temperature sensors with identical specification.
Moreover, four soil samples at each site were taken and their soil texture are analysed in order to calibrate the measured soil moisture. This network will contribute to soil moisture estimation from both passive and active microwave sensors.

\subsection{The Maqu network in a cold humid environment}

The Maqu soil moisture and soil temperature monitoring network was installed in July 2008 in the source water region of the Yellow River to the south of Maqu County in Gansu province, China. The network, consisting of 20 stations (Table 2) in an area of approximately $40 \mathrm{~km}$ by $80 \mathrm{~km}$, monitors continuously the soil moisture and soil temperature at different depths (from 5 to $80 \mathrm{~cm}$ below surface) at $15 \mathrm{~min}$ intervals. The Maqu Source Water Region of Yellow River Station for Climate and Environment Observation and Research of Chinese Academy of Sciences is located in the centre of this network. The objective of the network was to validate soil moisture products retrieved from coarse resolution satellite sensors and simulated by numerical models which remain a critical issue because of the large spatial gap between insitu soil moisture measurements and soil moisture estimates at $30-50 \mathrm{~km}$ spatial resolution and due to the typically high spatial variability of soil moisture.

The network is located at the north-eastern edge of the Tibetan Plateau $\left(33^{\circ} 30^{\prime}-34^{\circ} 15^{\prime} \mathrm{N}, 101^{\circ} 38^{\prime}-102^{\circ} 45^{\prime} \mathrm{E}\right)$ and at the first major meander of the Yellow River, where it is joined by the Black river. It covers the large valley of the river and the surrounding hills, characterised by a uniform land cover of short grassland used for grazing by sheep and yaks. The elevations of the stations range between $3430 \mathrm{~m}$ and $3750 \mathrm{~m}$ above mean sea level (a.s.l.) including typical landscapes with hills, valleys, river, wetlands, grassland and bare soil areas. Wetlands, with typically organic soils, characterise a large part of the valley, while silt loam soils can be found on the hills. According to the Koeppen Classification System, the climate at this site is defined as wet and cold, with dry winters and rainy summers due to the monsoon. More details for this network can be found in Dente et al. (2009, 2010). The locations of the stations were selected in order to monitor the area extensively at different altitudes and for different soil characteristics, 11 stations were installed in the valleys of the Yellow River and Black River, 3 stations in the valleys between hills, 4 stations on steep hill slopes and 2 stations in wetlands. Soil moisture and soil temperature are monitored at each station at different depths. Seven out of the 20 stations consist of 5 probes measuring at 5, 10, 20, 40 and $80 \mathrm{~cm}$ depths below surface, four stations measuring at $5,10,20$ and $40 \mathrm{~cm}$ and all other stations record data only at 5 and $10 \mathrm{~cm}$. Table 2 summarises the information related to each station of this network.

The capacitance EC-TM ECH $\mathrm{E}_{2} \mathrm{O}$ probe with 3 flat pins of $5.2 \mathrm{~cm}$ length was used to measure the dielectric permittivity of the soil surrounding the pins and obtain volumetric soil moisture with a standard calibration equation. The soil 
Table 1. Naqu network station information (station name, geographical coordinates, elevation above mean sea level (a.s.1.), depth of probes, location topography (TPG), land cover (LC), soil bulk density at $5 \mathrm{~cm}$ depth (BD), soil texture at $5-15 \mathrm{~cm}$ depth (STX), soil organic matter content at 5-15 cm depth (OMC), Not Available (NA)).

\begin{tabular}{llllllll}
\hline $\begin{array}{l}\text { Station name } \\
\text { (sensor ID) }\end{array}$ & Lat/Lon & $\begin{array}{l}\text { Elev. } \\
(\mathrm{m})\end{array}$ & $\begin{array}{l}\text { Depth of sensor } \\
\text { below surface } \\
(\mathbf{c m})\end{array}$ & TPG & LC & BD $\left(\mathrm{kg} \mathrm{m}^{-3}\right)$ & STX \\
\hline $\begin{array}{l}\text { Naqu Station } \\
(\text { SM5 }\end{array}$ & $31^{\circ} 22^{\prime} / 91^{\circ} 53^{\prime}$ & 4509 & $\begin{array}{l}2.5,7.5,15,30, \\
60\end{array}$ & Plain & Grassland & NA & $\begin{array}{l}\text { loot zone with high organic } \\
\text { matter, loamy sand with gravel }\end{array}$ \\
\hline $\begin{array}{l}\text { West Station } \\
\text { (TSM1) }\end{array}$ & $31^{\circ} 20^{\prime} / 91^{\circ} 49^{\prime}$ & 4506 & $\begin{array}{l}2.5,7.5,15,30, \\
60\end{array}$ & Plain & Grassland & NA & $\begin{array}{l}\text { root zone with loamy sand with } \\
\text { gravel }\end{array}$ \\
\hline $\begin{array}{l}\text { South Station } \\
\text { (TE2, SM2) }\end{array}$ & $31^{\circ} 19^{\prime} / 91^{\circ} 52^{\prime}$ & 4510 & $\begin{array}{l}2.5,7.5,15,30, \\
60\end{array}$ & Slope of wet land & Wetland & NA & $\begin{array}{l}\text { root zone with high organic } \\
\text { matter, loamy sand with gravel }\end{array}$ \\
\hline $\begin{array}{l}\text { North Station } \\
\text { (TE3, SM3) }\end{array}$ & $31^{\circ} 22^{\prime} / 91^{\circ} 52^{\prime}$ & 4507 & $\begin{array}{l}2.5,7.5,15,30, \\
60\end{array}$ & Slope on riverbank & Grassland & NA & $\begin{array}{l}\text { root zone with organic matter, } \\
\text { loamy sand with gravel }\end{array}$ \\
\hline $\begin{array}{l}\text { East Station } \\
\text { (TE4, SM4) }\end{array}$ & $31^{\circ} 22^{\prime} / 91^{\circ} 55^{\prime}$ & 4527 & $\begin{array}{l}2.5,7.5,15,30, \\
60\end{array}$ & Flat hill top & Grassland & NA & $\begin{array}{l}\text { root zone with organic matter, } \\
\text { loamy sand with gravel }\end{array}$ \\
\hline
\end{tabular}

(* TE - soil temperature probes, $\mathrm{SM}$ - soil moisture probes, TSM - soil temperature and moisture probes).

Table 2. Maqu network station information (station name, geographical coordinates, elevation a.s.l., depth of probes, location topography (TPG), land cover (LC), soil bulk density at $5 \mathrm{~cm}$ depth (BD), soil texture at 5-15 cm depth (STX), soil organic matter content at 5-15 cm depth (OMC), Not Available (NA)).

\begin{tabular}{|c|c|c|c|c|c|c|c|}
\hline Station Name/ID & Lat/Lon & Elev. (m) & Depth $(\mathrm{cm})$ & TPG & LC & $\mathrm{BD}\left(\mathrm{kg} \mathrm{m}^{-3}\right)$ & STX \\
\hline CST_01 & $33^{\circ} 53^{\prime} / 102^{\circ} 08^{\prime}$ & 3431 & $5,10,2040,80$ & River valley & Grass & NA & NA \\
\hline CST_02 & $33^{\circ} 40^{\prime} / 102^{\circ} 08^{\prime}$ & 3449 & $5,10,2040,80$ & River valley & Grass & NA & NA \\
\hline CST_03 & $33^{\circ} 54^{\prime} / 101^{\circ} 58^{\prime}$ & 3507 & $5,10,2040,80$ & Hill valley & Grass & NA & NA \\
\hline CST_04 & $33^{\circ} 46^{\prime} / 101^{\circ} 43^{\prime}$ & 3504 & $5,10,2040,80$ & Hill valley & Grass & NA & NA \\
\hline CST_05 & $33^{\circ} 40^{\prime} / 101^{\circ} 53^{\prime}$ & 3542 & $5,10,2040,80$ & Hill valley & Grass & NA & NA \\
\hline NST_01 & $33^{\circ} 53^{\prime} / 102^{\circ} 08^{\prime}$ & 3431 & $5,10,2040,80$ & River valley & Grass & 0.96 & Silt loam \\
\hline NST_02 & $33^{\circ} 53^{\prime} / 102^{\circ} 08^{\prime}$ & 3434 & 5,10 & River valley & Grass & 0.81 & Silt loam \\
\hline NST_03 & $33^{\circ} 46^{\prime} / 102^{\circ} 08^{\prime}$ & 3513 & 5,10 & Hill slope & Grass & 0.63 & Silt loam \\
\hline NST_04 & $33^{\circ} 37^{\prime} / 102^{\circ} 03^{\prime}$ & 3448 & 5,10 & River valley & Wetland grass & 0.26 & Silt loam \\
\hline NST_05 & $33^{\circ} 38^{\prime} / 102^{\circ} 03^{\prime}$ & 3476 & $5,10,2040$ & Hill slope & Grass & 0.75 & Silt loam \\
\hline NST_06 & $34^{\circ} 00^{\prime} / 102^{\circ} 16^{\prime}$ & 3428 & $5,10,2040$ & River valley & Grass & 0.81 & Silt loam \\
\hline NST_07 & $33^{\circ} 59^{\prime} / 102^{\circ} 21^{\prime}$ & 3430 & 5,10 & River valley & Grass & 0.58 & Silt loam \\
\hline NST_08 & $33^{\circ} 58^{\prime} / 102^{\circ} 36^{\prime}$ & 3473 & 5,10 & valley & Grass & 1.06 & Silt loam \\
\hline NST_09 & $33^{\circ} 54^{\prime} / 102^{\circ} 33^{\prime}$ & 3434 & 5,10 & River valley & Grass & 0.91 & Sandy loam \\
\hline NST_10 & $33^{\circ} 51^{\prime} / 102^{\circ} 34^{\prime}$ & 3512 & $5,10,2040$ & Hill slope & Grass & 1.05 & Loam-silt loam \\
\hline NST_11 & $33^{\circ} 41^{\prime} / 102^{\circ} 28^{\prime}$ & 3442 & 5,10 & River valley & Wetland grass & 0.24 & Silt loam \\
\hline NST_12 & $33^{\circ} 37^{\prime} / 102^{\circ} 28^{\prime}$ & 3441 & $5,10,2040,80$ & River valley & Grass & 1.02 & Silt loam \\
\hline NST_13 & $34^{\circ} 01^{\prime} / 101^{\circ} 56^{\prime}$ & 3519 & $5,10,2040$ & valley & Grass & 0.67 & Silt loam \\
\hline NST_14 & $33^{\circ} 55^{\prime} / 102^{\circ} 07^{\prime}$ & 3432 & 5,10 & River valley & Grass & 0.68 & Silt loam \\
\hline NST_15 & $33^{\circ} 51^{\prime} / 101^{\circ} 53^{\prime}$ & 3752 & 5,10 & Hill slope & Grass & 0.78 & Silt loam \\
\hline
\end{tabular}

temperature is measured using a thermistor located on the same probe. During the installation, soil samples were collected in order to determine the bulk density, particle size distribution and organic matter content. Most of the stations were installed in the most common silt loam soils in the area, with the wetland locations having the highest organic matter content (above $130 \mathrm{~g} \mathrm{~kg}^{-1}$ ). The soil texture in most stations is quite homogeneous at upper soil layers down to more than $40 \mathrm{~cm}$ depth (see Table 2) with main difference in the organic matter content between the stations. 
Table 3. Ngari network station information (station name, geographical coordinates, elevation a.s.l., depth of probes, location topography (TPG), land cover (LC), soil texture (STX), Not Available(NA)).

\begin{tabular}{|c|c|c|c|c|c|c|}
\hline Station ID & Lat/Lon & Elev. (m) & Depth (cm) & TPG & $\mathrm{LC}$ & STX \\
\hline SQ01 & $32^{\circ} 29^{\prime} / 80^{\circ} 04^{\prime}$ & 4306 & $5,5,5,10,20$ & flat & Desert & $\begin{array}{l}\text { Fine sand with gravel } \\
(0-10 \mathrm{~cm})\end{array}$ \\
\hline SQ02 & $32^{\circ} 30^{\prime} / 80^{\circ} 01^{\prime}$ & 4304 & $5,5,5,10,20$ & Gentle slope & Desert & $\begin{array}{l}\text { Fine sand with gravel } \\
(0-15 \mathrm{~cm})\end{array}$ \\
\hline SQ03 & $32^{\circ} 30^{\prime} / 79^{\circ} 58^{\prime}$ & 4278 & $5,5,10,20,40$ & Gentle slope & Desert (with sparse bushes) & $\begin{array}{l}\text { Fine sand with gravel } \\
(0-15 \mathrm{~cm})\end{array}$ \\
\hline SQ04 & $32^{\circ} 30^{\prime} / 79^{\circ} 57^{\prime}$ & 4269 & $5,5,10,20,40$ & Edge of a wetland & Sparse grass & Loam to loamy sand \\
\hline SQ05 & $32^{\circ} 30^{\prime} / 79^{\circ} 55^{\prime}$ & 4261 & $5,5,10,20,40$ & Edge of a marsh & Sparse grass & Loam with roots \\
\hline SQ06 & $32^{\circ} 30^{\prime} / 79^{\circ} 52^{\prime}$ & 4257 & $5,10,20,40,80$ & flat & Sparse grass & Sand \\
\hline SQ07 & $32^{\circ} 31^{\prime} / 79^{\circ} 50^{\prime}$ & 4280 & $5,5,10,20,40$ & flat & Desert (with sparse bushes) & Sand \\
\hline SQ08 & $32^{\circ} 33^{\prime} / 79^{\circ} 50^{\prime}$ & 4306 & $5,10,20,40,60$ & flat & Desert (maybe inundate in monsoon period) & Fine to coarse sand \\
\hline SQ09 & $32^{\circ} 27^{\prime} / 80^{\circ} 03^{\prime}$ & 4275 & $5,5,10,20,40$ & flat & Desert/river bed & $\begin{array}{l}\text { Fine sand with gravel } \\
\text { and bigger rocks } \\
(0-5 \mathrm{~cm})\end{array}$ \\
\hline SQ10 & $32^{\circ} 25^{\prime} / 80^{\circ} 00^{\prime}$ & 4275 & $5,10,20,40,80$ & flat & Grassland & $\begin{array}{l}\text { Fine sand with some } \\
\text { thick roots }(0-20 \mathrm{~cm})\end{array}$ \\
\hline SQ11 & $32^{\circ} 27^{\prime} / 79^{\circ} 58^{\prime}$ & 4274 & $5,10,20,40,60$ & flat & Grassland with bushes & $\begin{array}{l}\text { Fine sand }(0-5 \mathrm{~cm}) \text {, } \\
\text { loamy sand with roots } \\
(5-30 \mathrm{~cm})\end{array}$ \\
\hline SQ12 & $32^{\circ} 27^{\prime} / 79^{\circ} 56^{\prime}$ & 4264 & $5,10,20,40,60$ & flat & Edge of riverbed & $\begin{array}{l}\text { Fine to coarse sand } \\
(0-5 \mathrm{~cm}) \text {, } \\
\text { loamy with roots } \\
(5-40 \mathrm{~cm})\end{array}$ \\
\hline SQ13 & $32^{\circ} 26^{\prime} / 79^{\circ} 54^{\prime}$ & 4292 & $5,10,20,40,60$ & flat & Valley bottom & $\begin{array}{l}\text { Coarse sand }(0-5 \mathrm{~cm}) \text {, } \\
\text { fine to coarse sand with } \\
\text { roots }(5-30 \mathrm{~cm})\end{array}$ \\
\hline SQ14 & $32^{\circ} 27^{\prime} / 80^{\circ} 10^{\prime}$ & 4368 & $5,5,10,20,40$ & slope & Desert & $\begin{array}{l}\text { Fine sand with gravel } \\
(0-10 \mathrm{~cm}) \text {, } \\
\text { fine to coarse sand with } \\
\text { roots }(10-30 \mathrm{~cm})\end{array}$ \\
\hline SQ15 & $32^{\circ} 26^{\prime} / 80^{\circ} 11^{\prime}$ & 4387 & $5,10,20,30,50$ & flat & Bushes (1-2 m heights) & $\begin{array}{l}\text { Fine sand }(0-15 \mathrm{~cm}) \text {, } \\
\text { loam }(15-30 \mathrm{~cm})\end{array}$ \\
\hline SQ16 & $32^{\circ} 26^{\prime} / 80^{\circ} 04^{\prime}$ & 4288 & $5,10,20,30,60$ & flat & Desert ( $50 \mathrm{~m}$ from a riverbed) & $\begin{array}{l}\text { Loam with gravel and } \\
\text { with some clay layers } \\
(0-30 \mathrm{~cm})\end{array}$ \\
\hline Ali Station & $33^{\circ} 23^{\prime} / 79^{\circ} 42^{\prime}$ & 4288 & $5,10,20,40,80$ & flat & Grass & $\begin{array}{l}\text { Loamy sand with roots } \\
(0-20 \mathrm{~cm})\end{array}$ \\
\hline AL01 & $33^{\circ} 26^{\prime} / 79^{\circ} 44^{\prime}$ & 4262 & $5,10,20,40,60$ & flat & Sparse grass & $\begin{array}{l}\text { Fine to coarse sand } \\
\text { with roots }(0-10 \mathrm{~cm})\end{array}$ \\
\hline AL02 & $33^{\circ} 27^{\prime} / 79^{\circ} 37^{\prime}$ & 4266 & $5,10,20,30,50$ & flat & Sparse grass & $\begin{array}{l}\text { Coarse sand with gravel } \\
(0-35 \mathrm{~cm})\end{array}$ \\
\hline AL03 & $33^{\circ} 27^{\prime} / 79^{\circ} 37^{\prime}$ & 4261 & $5,10,20,40,60$ & flat & Grass at the edge of a wetland & $\begin{array}{l}\text { Coarse sand with gravel } \\
(0-35 \mathrm{~cm})\end{array}$ \\
\hline
\end{tabular}

Since the dielectric properties of the soils depend on soil texture and salinity, a specific calibration for the soils in Maqu was carried out using soil rings, with which the uncertainty of approximately $3 \%$ given by the generic calibration equation (default by the datalogger) valid for all fine textured mineral soils can be reduced to $1-2 \%$. The calibration has reduced RMSD between the volumetric soil moisture measured by the rings and that by the probes from 0.06 to $0.02 \mathrm{~m}^{3} \mathrm{~m}^{-3}$ which can be considered as the absolute accuracy of each station of this network (Dente et al., 2009).

\subsection{The Ngari network in a cold arid environment}

In this study area twenty soil moisture and soil temperature monitoring stations were installed in June 2010 in the Ngari prefecture in the western part of the Tibetan Plateau. Within this region, ITP has established the Ngari Station for Desert Environment Observation and Research of the Chinese Academy of Sciences (NASDE/CAS) in 2008, which is located $1-2 \mathrm{~km}$ from the small village Rutok and about $8 \mathrm{~km}$ from the Pangang Tso Lake, an inland lake that crosses the border with India. Four soil moisture and soil temperature 
stations were installed in the flat area in the vicinity of NASDE/CAS primarily in support of the surface energy balance measurements. The other 16 soil moisture and soil temperature stations were installed near the city Shiquanhe, located about $100 \mathrm{~km}$ south east of NASDE. This desert environment is dominated by the Shiquanhe river that cuts through the valley. As such, the area includes a range of soil moisture conditions from very wet near the river to very dry at the higher situated locations. Table 3 lists the location, topography, land cover, and soil texture of each station.

\section{Coarse resolution satellite soil moisture products}

Many remote sensing studies have concluded that lowfrequency microwave radiometers should offer the best performance for soil moisture retrievals (e.g. Jackson et al., 1999). As a result, recent initiatives for dedicated soil moisture missions have chiefly relied on passive microwave techniques in the frequency range from 1 to $2 \mathrm{GHz}$ (L-band). The first mission is the Soil Moisture and Ocean Salinity (SMOS) satellite of ESA launched in November 2009. SMOS has a spatial resolution of about $40 \mathrm{~km}$ and a revisit time of about 2 days (Kerr et al., 2001). The second soil moisture satellite is foreseen for launch in 2014 by NASA, the Soil Moisture Active Passive (SMAP) satellite (Entekhabi et al., 2010). Improved algorithms have been also continuously developed to derive soil moisture from existing operational satellite platforms, from passive microwave instruments like the Advanced Microwave Scanning Radiometer (AMSR-E) (Njoku et al., 2003; Owe et al., 2008), and from active microwave instruments such as the scatterometers on-board of the European remote sensing satellite (ERS-1/2) (SCAT) (Wagner et al., 2003) and the first polar-orbiting satellite dedicated to operational meteorology (METOP) (ASCAT) (Bartalis et al., 2007).

For active microwave sensors the application of change detection algorithms, by exploiting the unique sensor design of the SCAT and ASCAT sensors, was found useful for soil moisture retrieval (Wagner et al., 2003). Although current understanding of the attenuation of microwaves by vegetation is still rather poor, various experimental studies (e.g. Su et al., 1997; Wen and Su, 2003a, b) showed the presence of significant soil response at C-band frequencies even in the case of vegetated areas when observed at lower incidence angles. Due to the unique antenna design of the scatterometers three measurements are made of any surface area (fore, mid and aft beam at a $45^{\circ}, 90^{\circ}$ and $135^{\circ}$ azimuth angle with respect to the satellite track on the right side of SCAT and on each side of ASCAT) with different incidence angles. As a result of the stability of the satellite and the large footprints of the measurements, yearly cycles of the backscatter-incidence angle relationship can be established for correcting seasonal vegetation effects. When surface roughness is assumed to have a constant contribution in time, its influence is mini- mized in a change detection algorithm. By assuming a typical yearly vegetation cycle and hence its influence on the backscatter-incidence angle relationship, the vegetation effects can be removed. In the resulted backscattering signal, only information about soil moisture variations is then preserved. Assigning the historically lowest and highest values of observed backscattering signal to dry $(0 \%)$ and wet $(100 \%)$ references respectively, a time series of relative soil moisture can be derived for the first few centimetres of the soil. These values can be converted to absolute soil moisture using soil properties. Wen and Su (2003a, b) have also attempted to retrieve soil moisture with the three (fore, mid and aft beam) backscattering measurements with a simple radiative transfer model. Similar analyses were also reported by Frison et al. (1997) and Woodhouse and Hoekman (2000).

For passive microwave remote sensing a soil moisture dataset was obtained from different satellites sensors going back to late 1978 using the Land Parameter Retrieval Model (LPRM, Owe et al., 2008) by retrieving simultaneously the surface soil moisture and vegetation optical depth (Meesters et al., 2005). The land surface temperature is derived separately from Ka-band (Holmes et al., 2009). A unique feature of this method is that it may be applied at any microwave frequency, making it very suitable to exploit all available passive microwave data from historic satellites. LPRM produced volumetric soil moisture $\left(\mathrm{m}^{3} \mathrm{~m}^{-3}\right)$ of approximately the first 1-2 centimetres below surface for C-band microwave observations. The data product to be validated was generated by the LPRM algorithm applied to AMSR-E data and will be called the AMSR-E soil moisture data in the rest of this paper.

The accuracy of the soil moisture products from coarse resolution satellite sensors have been subject of various previous studies. These data sets were validated over regional limited networks (e.g. Albergel et al., 2009; Gruhier et al., 2010; Sinclair and Pegram, 2010) and evaluated against model data (Wagner et al., 2003; Rüdiger et al., 2009; de Rosnay et al., 2008). These studies found high correlations with in situ observations in semi arid regions and somewhat lower correlations in agricultural areas. Recent assimilation studies support the positive findings of the validation efforts (Drusch et al., 2008; Scipal et al., 2008).

De Jeu et al. (2008) highlighted differences and limitations of active and passive soil moisture products (i.e. Radio Frequency Interference, RFI, in AMSR-E, misinterpretation of ERS in desert regions) in a global evaluation study. These results suggest the potential to merge different soil moisture products into one superior soil moisture dataset as undertaken in the WACMOS (Water Cycle Multimission Observation Strategy) project (Su et al., 2010; Dorigo et al., 2010; Liu et al., 2011). However, the validity and accuracy of these data for the Tibetan Plateau have not been assessed due to lack of in-situ reference data where extreme climate conditions have made in-situ measurements very difficult. 

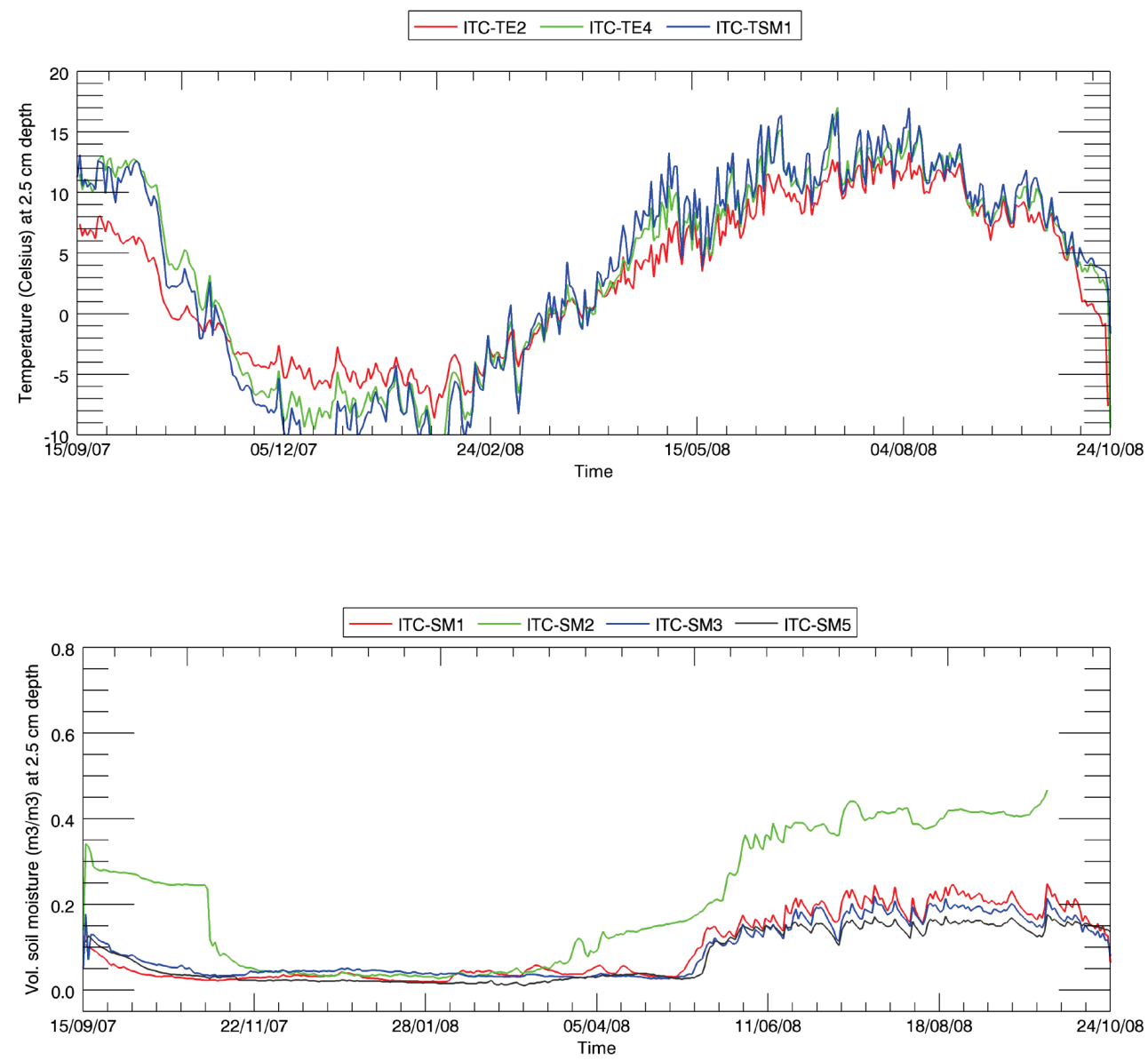

Fig. 2. Soil temperature (upper panel) and soil moisture (lower panel) measured at a $2.5 \mathrm{~cm}$ depth in Naqu network area. Shown are records of individual data loggers from 15 September 2007 to 24 October 2998. South station (ITC-TE2 and ITC-SM2 for soil temperature and soil moisture respectively) is a wetland site. Naqu Station (ITC-SM5 for soil moisture), West Station (ITC-TSM1 for soil temperature), North Station (ITC-TE3, ITC-SM3 for soil temperature and soil moisture respectively), and East Station (ITC-TE4 for temperature only) are grassland sites with sparse grass coverage.

With the operational Naqu and Maqu networks (data from the Ngari net work is not available at the writing time), assessment of three datasets (henceforth the AMSR-E products, the ASCAT-L2 and the SMOS products) was conducted and results are presented in next section.

\subsection{AMSR-E soil moisture data}

The AMSR-E products were retrieved from http://www.geo. vu.nl/ jeur/lprm/ which provides daily 0.25 degree surface soil moisture and land surface temperature data from AMSRE observations; the night-time overpass products are used because the daytime overpass data have major uncertainties caused by temperature variations.

\subsection{ASCAT-L2 soil moisture data}

The ASCAT-L2 products were retrieved from the EUMETSAT archive which link can be found at http://www.ipf.tuwien.ac.at/radar/. The ASCAT-L2 products are global coarse resolution soil moisture estimates (25$50 \mathrm{~km}$ ) derived from backscatter measurements acquired with scatterometers onboard the METOP satellite, with relative values scaled between $0 \%$ and $100 \%$ representing dry and saturation conditions respectively. Using the soil database of FAO (2003) (Reynolds et al., 1999) this dataset is rescaled to volumetric soil moisture to be compatible with other satellite data and easy for comparison with the in-situ measurements.

\subsection{SMOS soil moisture data}

After the successful launch of SMOS in November 2009 and following the first six months of SMOS commissioning phase to test the functionalities of the spacecraft and instrument, SMOS has been in routine operation since May 2010 and has been providing data products to the science community for a variety of applications. The SMOS soil moisture 


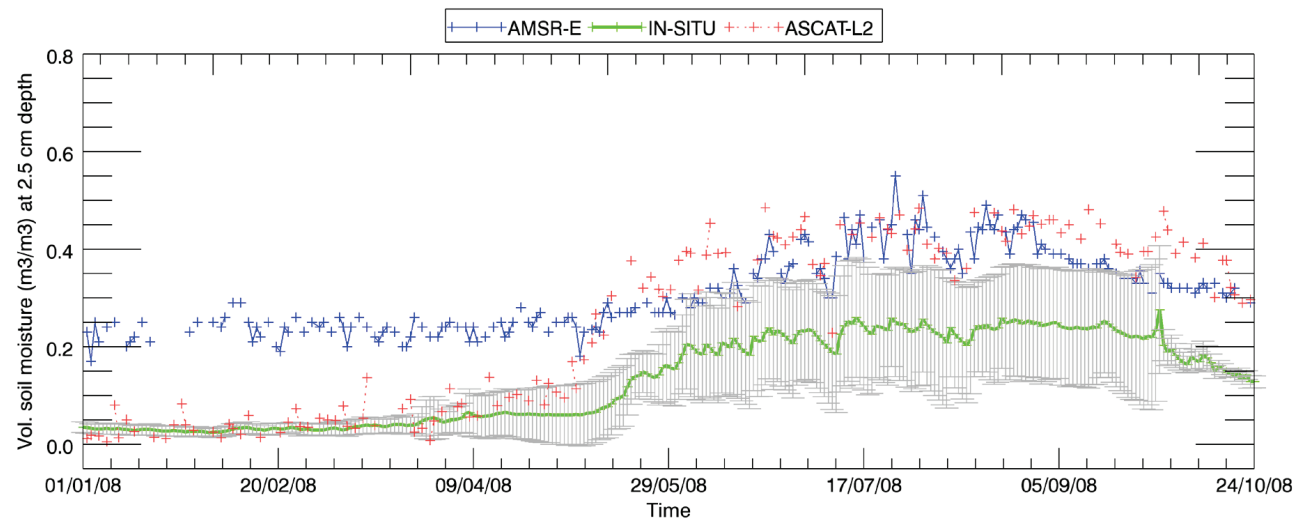

Fig. 3. Soil moisture retrievals from AMSR-E (blue) and ASCAT-L2 (red) compared to in situ measured soil moisture at a $2.5 \mathrm{~cm}$ soil depth in Naqu network area (green line with range (error bars) given by one standard deviation around the mean).

level 2 data are recently released after reprocessing for the year 2010. More information on the reprocessing, data improvements and instrument setting changes concerning the reprocessed dataset from April 2011 has been prepared by ESA. The Algorithm Theoretical Basis Document describes the details used in the reprocessing (SMOS, 2011). The data are released to the calibration and validation $(\mathrm{Cal} / \mathrm{Val})$ team for a first evaluation in April 2011 (ESLs+ARRAY, 2011).

\section{Results and discussion}

\subsection{Naqu network}

Measured soil temperature and soil moisture values by probes at $2.5 \mathrm{~cm}$ depth at Naqu network are plotted in Fig. 2 for the period from 15 September 2007 to 24 October 2008. The general patterns of soil temperature time series are similar for other years for this region, so our analysis will focus on this period. The first freezing event occurred on 19 October 2007 and marked a period of freezing and thawing till the beginning of November when it permanently froze at this depth $(2.5 \mathrm{~cm})$, during which the volumetric soil moisture dropped abruptly from above 0.2 to below $0.1 \mathrm{~m}^{3} \mathrm{~m}^{-3}$ for the wetland site (south station, i.e. ITC-TE2 and ITC-SM2 for soil temperature and soil moisture respectively). This marked the winter period until mid April 2008 when the gradual warming and thawing took place. The increase of the soil moisture till the beginning of June is dominated by the thawing of frozen soil at the wetland location. From the temperature and soil moisture point of view, this period may be defined as the monsoon onset period. In the monsoon period from the beginning of June to the end of September, the soil moisture mainly reacts to monsoon precipitation and is maintained at around saturation of $0.4 \mathrm{~m}^{3} \mathrm{~m}^{-3}$ at the wetland station.

At the grassland stations (West station, i.e. ITC-TSM1 for soil temperature and soil moisture; East station i.e. ITC-
TE4 for soil temperature; Naqu station, i.e. ITC-SM5 for soil moisture), the patterns of the temperature time series are similar to that at the wetland station, but the temperatures are in general higher in summer period and lower in winter period, reflecting the different thermodynamic properties of local soils regulated by the water content because of the higher thermal capacity of water compared to those of soil. The soil moisture time series at the grassland locations are characterized by very stable and dry conditions during the winter period at 0.01 to $0.05 \mathrm{~m}^{3} \mathrm{~m}^{-3}(0.01$ is about the absolute precision of the probes) indicating a dielectrically dry soil and following the precipitation pattern closely in the monsoon period and maintain with maximum values around $0.25 \mathrm{~m}^{3} \mathrm{~m}^{-3}$. The small differences in soil moisture at the different stations are explained by the difference in local topography and soil organic contents (amounts of roots) and are consistent with field inspection.

Figure 3 displays a comparison of soil moisture products from AMSR-E and ASCAT-L2 with the in-situ soil moisture measurements (at $2.5 \mathrm{~cm}$ depth) at the Naqu network area for the monsoon period. This period is chosen based on the availability of the different satellite data products because in the retrievals certain areas and periods are excluded (based on land use and/or temperature criteria) resulting in lack of data for the Naqu area in winter period. The used in-situ soil moisture is the simple averages at the available stations, which is considered justified for the purpose of comparison with coarse resolution satellite data because of the uncertainties in the geolocation and precise footprints of the satellite pixels $(25 \sim 50 \mathrm{~km})$.

It is observed while both retrievals follow the gradual increasing pattern from winter to monsoon period of soil moisture in Naqu network area, there are dramatic differences in the magnitudes. Both overestimate the areal mean of in-situ measurements by about $100 \%$ in the monsoon period (May to August). In winter period, AMSR-E grossly overestimates the in-situ measurements, while ASCAT-L2 estimates 


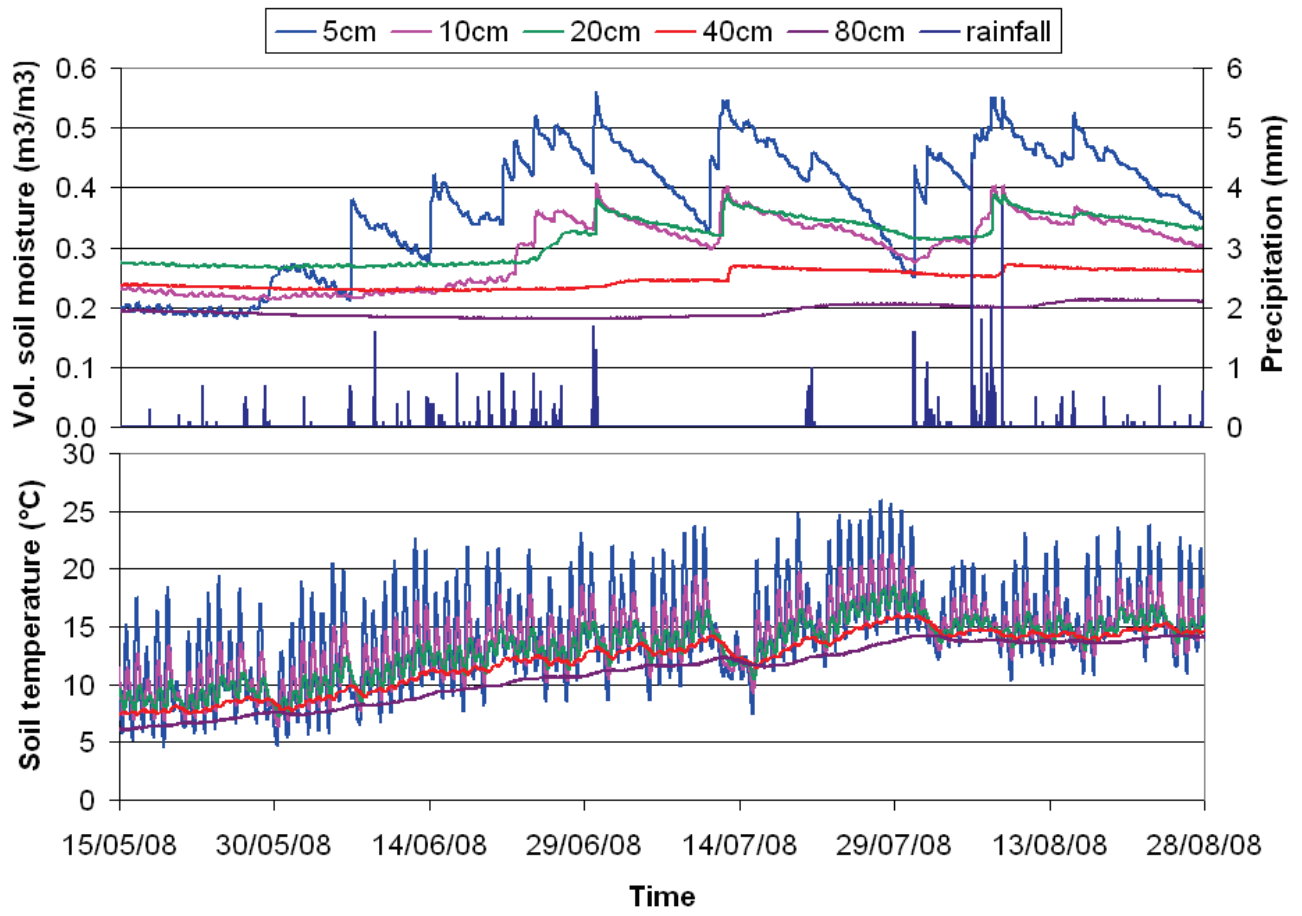

Fig. 4. Volumetric soil moisture and soil temperature at different depths at station CST_01 compared with precipitation data collected at CARRERI/CAS micrometeorological tower.

Table 4. Validation statistics data for Naqu network area. RMSE is the Root Mean Squared Error (difference) between a satellite product and in-situ observation $\left(\mathrm{m}^{3} \mathrm{~m}^{-3}\right) ; R$ is the coefficient of correlation between the previous two (-); and MD is the mean difference between the two $\left(\mathrm{m}^{3} \mathrm{~m}^{-3}\right)$. No. is the number of data points used.

\begin{tabular}{llll}
\hline $\begin{array}{l}\text { Period of in-situ } \\
\text { measurements }\end{array}$ & AMSR-E & ASCAT-L2 & SMOS \\
\hline 01.2008-24.10.2008 & RMSE=0.174 & RMSE=0.149 & - \\
& $R=0.895$ & $R=0.964$ & \\
& MD=0.17 & MD=0.122 & \\
& No.=205 & No.=144 & \\
\hline Winter period & RMSE=0.206 & RMSE=0.022 & - \\
01.2008-02.2008 & $R=0.085$ & $R=0.028$ & \\
& MD=0.204 & MD=0.017 & \\
& No.=30 & No.=26 & \\
\hline Monsoon period & RMSE=0.172 & RMSE=0.190 & - \\
06.2008-08.2008 & $R=0.829$ & $R=0.729$ & \\
& MD =0.166 & MD=0.186 & \\
& No. $=75$ & No. $=46$ & \\
\hline
\end{tabular}

are close to the in-situ measurements since the area is frozen and the assumption of dry soil in ASCAT-L2 retrieval appears reasonable. The deviation in AMSR-E products must be caused by the assumptions in roughness parameterisation and the surface temperature retrieval, since this area is only sparsely vegetated, assumptions related to the single scattering albedo and optical thickness shall not have defining influences. It is therefore reasoned that the used constant roughness parameter may not be valid for this area, because from the field works, it can be observed that the variability in local roughness in this area can be quite large. The major uncertainty may be attributed to the retrieval of the surface temperature necessary for deriving the surface emissivity and thus soil moisture. The ASCAT-L2 products systematically overestimate the surface soil moisture in this network area in the monsoon period. The average soil moisture in this area is usually very low and not more than $0.25 \mathrm{~m}^{-3} \mathrm{~m}^{-3}$ on average in the monsoon period, and because of its frozen conditions in winter, the soil moisture measured by the in-situ probes (Fig. 3) and sensed by microwaves should be practically identical to those of a dry soil in winter. While it has been reported by previous studies (e.g. Dorigo et al., 2010) that the change detection algorithm is unreliable in arid conditions, it is for the first time to observe such a big uncertainty in cold semiarid conditions; the use of this dataset for comparable environmental conditions can only be recommended if assessment with in-situ data can be carried out to assure the consistency with the actual hydrological situation. Detailed validation statistics data for Naqu network area are given in Table 4, for the whole period from 1 January till 24 October 2008 and separated into monsoon and winter period, thus providing quantitative information for the uncertainties in the different periods. 
Despite the limited numbers of in-situ stations in this network, the areal average soil moisture may be considered representative of the Naqu area. This is also confirmed by measurements conducted at the GEWEX CEOP stations operated in the same area in 2003 with an average soil moisture between $0.2-0.3 \mathrm{~m}^{3} \mathrm{~m}^{-3}$ as well as data assimilation results reported in Yang et al. (2007). It is expected that the newly established stations in July 2010 will definitively provide the most comprehensive assessment of the uncertainties of the various satellite products.

\subsection{Maqu network}

An example of the collected volumetric soil moisture and soil temperature data are shown in Fig. 4 with characteristic patterns from dry to wet and from cold to warm conditions responding to the weather events recorded at a micrometeorological tower of CAREERI/CAS (located next to station CST_01) from mid May to end August 2008. The $5 \mathrm{~cm}$ soil moisture trend follows closely precipitation measured at the tower, showing a good response of the $\mathrm{ECH}_{2} \mathrm{O}$ probes to soil wetting (precipitation) and drying (evaporation) (rainfall data were missing between 4 and 17 July 2008). The soil at 10 and $20 \mathrm{~cm}$ depth are dryer and show a smoother trend than the surface layer. The lower soils, at 40 and $80 \mathrm{~cm}$ depth, are dryer and respond much slower to precipitation, the soil moisture at these depths increases only slowly after about two months from the beginning of the rainy monsoon season. The whole soil profile warms up during the monsoon season while the soil temperature at shallow depth (at 5 and $10 \mathrm{~cm}$ ) decreases after each precipitation event indicating cooling as a result of reduction of solar radiation during the precipitation event as well as by heat loss to colder precipitating water and cooling by evaporation.

Figure 5 shows the calibrated volumetric soil moisture measured at $5 \mathrm{~cm}$ depth at all stations from 1 July to $30 \mathrm{Au}-$ gust 2008. There is a large temporal variability of soil moisture in Maqu in this period of the year, with rapid increase in soil moisture responding to precipitation events and gradual decrease of it due to evaporation. The interesting spatial soil moisture variability in the area is attributed to the soil texture differences with very high soil moisture values $\left(0.5 \sim 0.7 \mathrm{~m}^{3} \mathrm{~m}^{-3}\right)$ corresponding to soils with higher organic content and lower one $\left(0.1 \sim 0.3 \mathrm{~m}^{3} \mathrm{~m}^{-3}\right)$ to a sandy loam soil. Other measurements in between these extremes are collected in silt loam soils with low organic content, with their variability attributing to topographic differences in the station locations, hill slope or valley bottom as well as exposure to solar radiation.

Figure 6 shows soil moisture products from AMSR-E and ASCAT-L2 compared to measured values at $5 \mathrm{~cm}$ soil depth in Maqu network area from 1 July 2008 to 31 July 2009. For AMSR-E products, the Root Mean Square Error (RMSE), the Mean Difference (MD) and the coefficient of correlation $(R)$ (Table 5) indicate good agreement with in-situ
Table 5. Validation statistics for Maqu network area in year 2008-2009 and 2009-2010. RMSE is the Root Mean Squared Error (difference) between a satellite product and in-situ observation $\left(\mathrm{m}^{3} \mathrm{~m}^{-3}\right) ; R$ is the coefficient of correlation between the previous two (-); and MD is the mean difference between the two $\left(\mathrm{m}^{3} \mathrm{~m}^{-3}\right)$. No. is the number of data points used.

\begin{tabular}{|c|c|c|c|}
\hline Period of comparison & AMSR-E & ASCAT-L2 & SMOS \\
\hline $05.2008-07.2010$ & $\begin{array}{l}\mathrm{RMSE}=0.139 \\
R=0.302 \\
\mathrm{MD}=0.104 \\
\text { No. }=684\end{array}$ & $\begin{array}{l}\mathrm{RMSE}=0.084 \\
R=0.877 \\
\mathrm{MD}=0.068 \\
\text { No. }=541\end{array}$ & \\
\hline 07.2008-07.2009 & $\begin{array}{l}\mathrm{RMSE}=0.132 \\
R=0.351 \\
\mathrm{MD}=0.095 \\
\text { No. }=335\end{array}$ & $\begin{array}{l}\mathrm{RMSE}=0.089 \\
R=0.876 \\
\mathrm{MD}=0.072 \\
\text { No. }=268\end{array}$ & \\
\hline 07.2009-07.2010 & $\begin{array}{l}\mathrm{RMSE}=0.144 \\
R=0.216 \\
\mathrm{MD}=0.11 \\
\text { No. }=333\end{array}$ & $\begin{array}{l}\mathrm{RMSE}=0.081 \\
R=0.855 \\
\mathrm{MD}=0.066 \\
\text { No. }=260\end{array}$ & $\begin{array}{l}\mathrm{RMSE}=0.094 \\
R=0.718 \\
\mathrm{MD}=0.083 \\
\text { No. }=38\end{array}$ \\
\hline $\begin{array}{l}\text { Winter period } \\
2008-2009 \\
11.2008-02.2009\end{array}$ & $\begin{array}{l}\mathrm{RMSE}=0.223 \\
R=0.238 \\
\mathrm{MD}=0.201 \\
\text { No. }=96\end{array}$ & $\begin{array}{l}\mathrm{RMSE}=0.083 \\
R=0.814 \\
\mathrm{MD}=0.07 \\
\text { No. }=82\end{array}$ & \\
\hline $\begin{array}{l}\text { Winter period } \\
2009-2010 \\
11.2009-02.2010\end{array}$ & $\begin{array}{l}\mathrm{RMSE}=0.222 \\
R=0.140 \\
\mathrm{MD}=0.201 \\
\text { No. }=92\end{array}$ & $\begin{array}{l}\mathrm{RMSE}=0.086 \\
R=0.798 \\
\mathrm{MD}=0.077 \\
\text { No. }=70\end{array}$ & \\
\hline $\begin{array}{l}\text { Monsoon period } 2008 \\
06.2008-08.2008\end{array}$ & $\begin{array}{l}\mathrm{RMSE}=0.051 \\
R=0.723 \\
\mathrm{MD}=0.04 \\
\text { No. }=80\end{array}$ & $\begin{array}{l}\mathrm{RMSE}=0.063 \\
R=0.652 \\
\mathrm{MD}=0.049 \\
\text { No. }=64\end{array}$ & \\
\hline $\begin{array}{l}\text { Monsoon period } 2009 \\
06.2009-08.2009\end{array}$ & $\begin{array}{l}\mathrm{RMSE}=0.063 \\
R=0.292 \\
\mathrm{MD}=0.052 \\
\text { No. }=80\end{array}$ & $\begin{array}{l}\mathrm{RMSE}=0.095 \\
R=0.388 \\
\mathrm{MD}=0.080 \\
\text { No. }=63\end{array}$ & \\
\hline $\begin{array}{l}\text { Monsoon period } 2010 \\
06.2010-07.2010\end{array}$ & $\begin{array}{l}\mathrm{RMSE}=0.087 \\
R=0.082 \\
\mathrm{MD}=0.078 \\
\text { No. }=54\end{array}$ & $\begin{array}{l}\mathrm{RMSE}=0.069 \\
R=0.38 \\
\mathrm{MD}=0.055 \\
\text { No. }=41\end{array}$ & \\
\hline
\end{tabular}

measurements in the monsoon periods; similar conclusion can be drawn for ASCAT-L2 products.

While the statistical evaluations reveal good average agreements in the monsoon periods (Table 5), more interesting details can be seen for different seasons. It can be observed that AMSR-E products tend to overestimate the soil moisture which is particularly so in winter period by $0.30 \mathrm{~m}^{3} \mathrm{~m}^{-3}$ (it is noted that many AMSR-E estimates are missing). In the monsoon period, the AMSR-E products are good within the spatial variability of the in-situ measurements (as indicated by the mean and the range given by standard deviations) except at the beginning of the monsoon season around April when unexplained large overestimates occur.

The ASCAT-L2 products also overestimate the soil moisture in the monsoon period, but clearly underestimate it in 


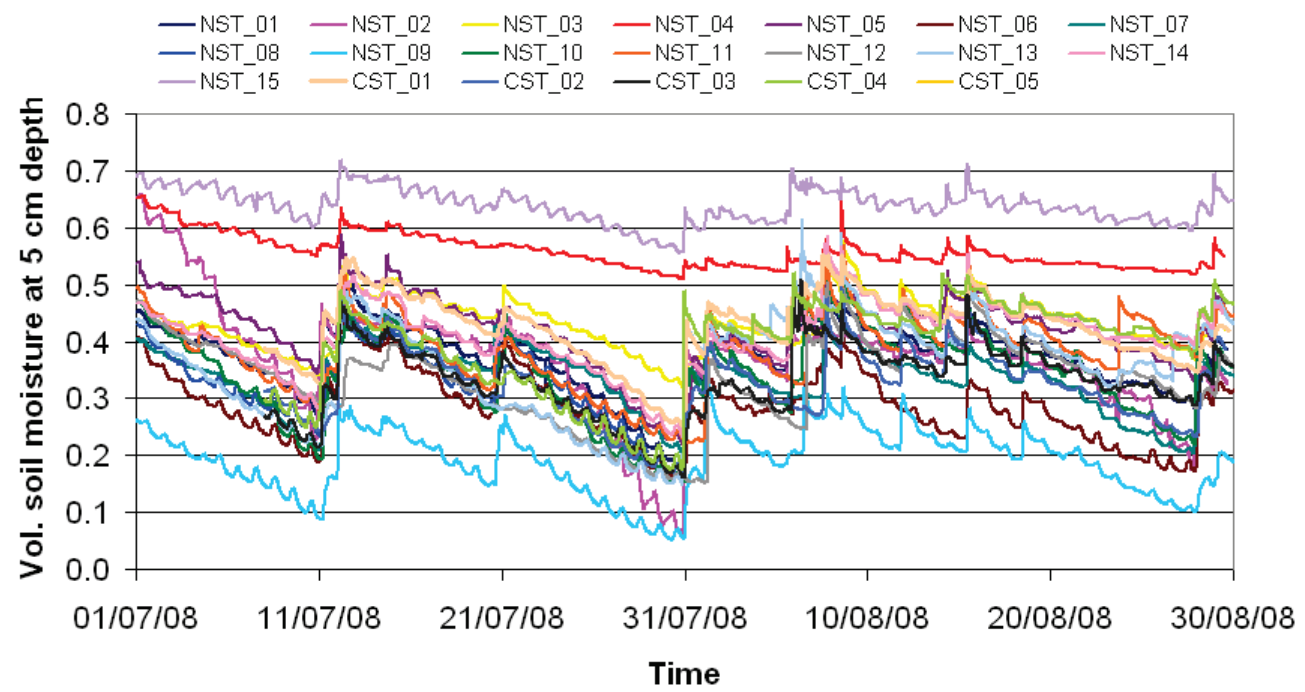

Fig. 5. Calibrated volumetric soil moisture measured at $5 \mathrm{~cm}$ depth at all Maqu network stations (detailed information for each station is given in Table 2).
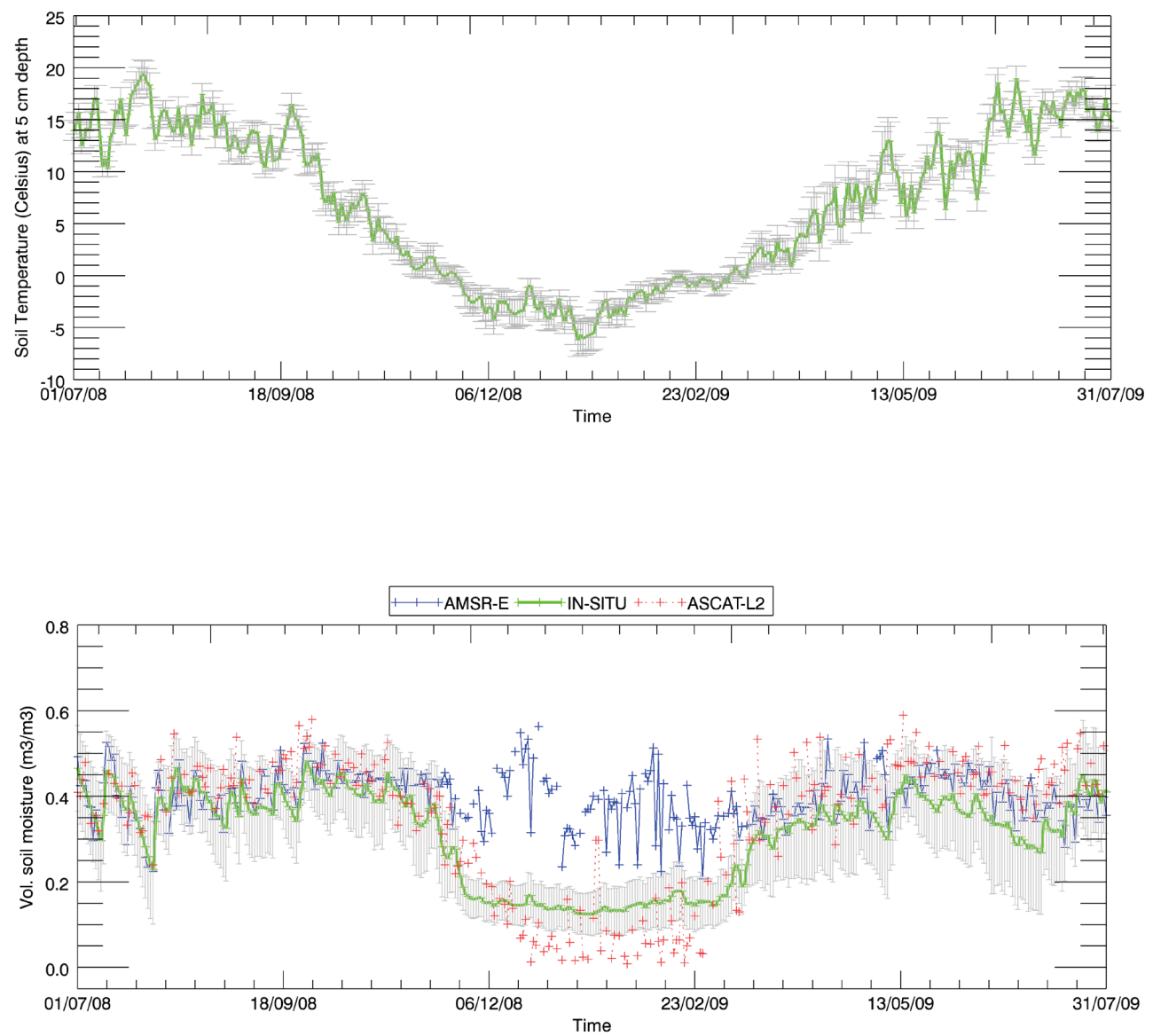

Fig. 6. Soil temperature (upper panel) and soil moisture (lower panel) measured at $5 \mathrm{~cm}$ soil depth in Maqu network area, showing the average (solid green line) and one standard deviation around the mean (error bars) from 1 July 2008 to 31 July 2009 , using all 20 stations. The AMSR-E (+ in blue) and ASCAT-2 soil moisture retrieval (+ in red) for the Maqu area are also shown. 


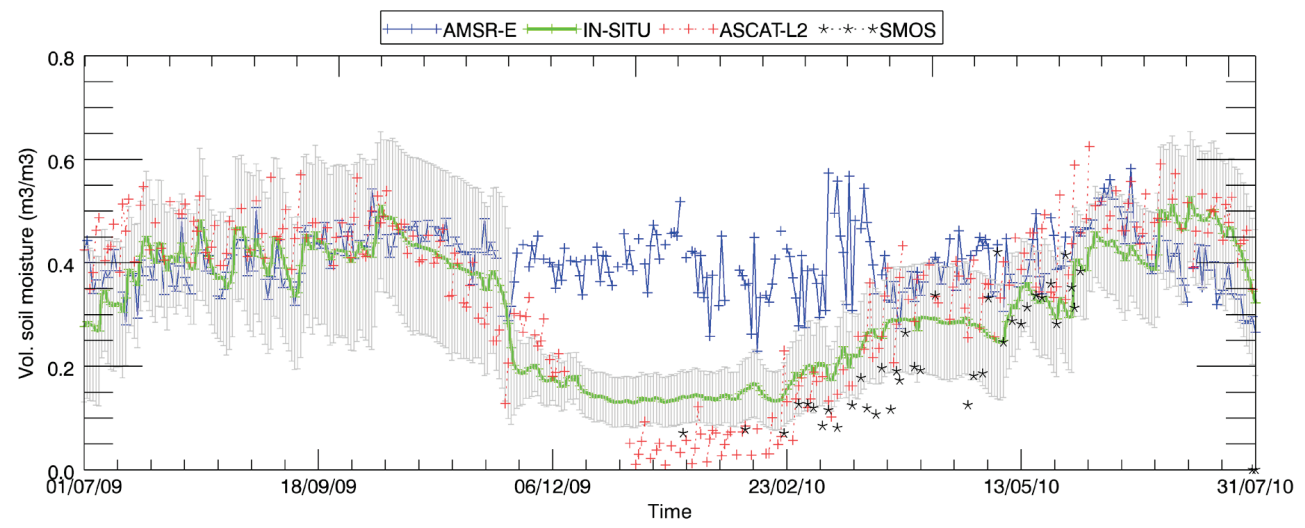

Fig. 7. The AMSR-E (+ in blue), ASCAT-L2 (+ in red) and SMOS soil moisture retrieval (* in black) for the Maqu area compared to soil moisture measured at $5 \mathrm{~cm}$ soil depth in Maqu network area, showing the average (solid green line) and one standard deviation around the mean (error bars) from 1 July 2009 to 31 July 2010, using all 20 stations.

the winter period. While the overestimation is in general related to precipitation events as also recorded by the in-situ data, some of the extreme peaks in the estimates cannot be explained satisfactorily. The underestimation by about 0.15 $\mathrm{m}^{3} \mathrm{~m}^{-3}$ in the winter period is considered caused by the soil freezing when it appears similar to dry soil to microwave observation. It is however to note that there are flags in both AMSR-E and ASCAT-L2 products that when applied would result in no data in winter for many areas on the Tibetan Plateau but we choose to evaluate the complete data sets and have discovered the opposite behaviour of the two data products which may be utilised to produce a combined and more consistent dataset (e.g. Su et al., 2010).

Figure 7 shows soil moisture products from AMSR-E, ASCAT-L2 and SMOS compared to measured values at $5 \mathrm{~cm}$ soil depth in Maqu network area from 1 July 2009 to 31 July 2010. Very similar conclusions can be drawn for AMSR-E and ASCAT-L2 data. For the SMOS data, although the data availability is rather limited, the good temporal correspondence to the in-situ measurements from the winter to monsoon period (Fig. 7) and the favourable statistics (Table 5) testify the promising potential of the SMOS data.

Finally it should be pointed out that the in-situ measurements indicated soil moisture around the values of 0.15 $0.2 \mathrm{~m}^{3} \mathrm{~m}^{-3}$ in winter period which may seem counter intuitive that the soil was not completely frozen when the soil temperature was below freezing point. It should be noted however, that confined liquid water within a porous material submitted to frost action does not simultaneously freeze at the same temperature which is commonly attributed to the interaction between water and pore surfaces, water impurity, or supercooling. As a consequence, an initially water-saturated porous material remains filled by both ice and liquid water with temperature down to at least $-80^{\circ} \mathrm{C}$ (Jehng et al., 1996 from Fabbri et al., 2006).

\section{Conclusions}

The Tibetan Plateau observatory of plateau scale soil moisture and soil temperature (Tibet-Obs) is presented in detail consisting of three regional scale in-situ reference networks, the Naqu network in a cold semiarid climate, the Maqu network in a cold humid climate and the Ngari network in a cold arid climate. These networks provide a representative coverage of the different climate and land surface hydrometeorological conditions on the Tibetan plateau. The obtained data are analysed to ensure the consistency with the regional climatic conditions and for the purpose of serving as reference for validation of coarse resolution satellite and modeling soil moisture products. Each network with its mean and variance of measurements (presented as average and range given by standard deviations) of soil temperature and soil moisture is representative of a particular situation on the Tibetan Plateau. Comparison of three satellite retrievals and products are carried out confirming findings of previous studies with regard to AMSR-E data and ASCAT-L2 products for semiarid areas but revealing unreported uncertainties for cold seasons.

Some important findings are obtained in this study for the Naqu area as a cold semiarid area where AMSR-E and ASCAT-L2 products overestimate by $0.2 \sim 0.3 \mathrm{~m}^{3} \mathrm{~m}^{-3}$ the regional soil moisture in the monsoon periods. In the winter periods, the AMSR-E data are not reliable at all, indicating needs in improving the retrieval algorithms in particular for the surface temperature. For similar cold semiarid conditions on the Tibetan Plateau, due to the unexplained big uncertainty, the use of these datasets are not recommended before a rigorous assessment of the algorithm with in-situ data can be carried out to explain the reasons of deviations and to improve the consistency with the actual hydrological situation.

For the cold humid Maqu network area it is concluded that soil moisture products from AMSR-E, ASCAT-L2 have comparable accuracy as reported by previous studies in the humid 
monsoon period. The AMSR-E products overestimate and ASCAT-L2 products underestimate soil moisture in the winter period significantly. But the opposing behaviours of both data sets may be used to generate a more useful data for the winter periods. A preliminary evaluation of SMOS data indicates its promising feature, but apparently needs much more data to derive more concrete conclusions.

We conclude that global coarse resolution soil moisture products are useful but exhibit big uncertainties in cold semiarid regions on the Tibetan Plateau that need to be characterised and improved before operational use of these data. The in-situ soil moisture and soil temperature measurements are valuable references in this particular environment and can also be used for assessment of global model products that shall be the topics of future investigations.

Acknowledgements. This work was funded in part by the ESA-MOST Dragon I/II programme (Drought Monitoring, Prediction and Adaptation under Climatic Changes project and Young Scientists Support), the European Commission CEOP - AEGIS project (Call FP7-ENV-2007-1 Grant nr. 212921) (http://www.ceop-aegis.org/), the ESA STSE WACMOS project (www.WACMOS.org) and the Innovation Project of the Chinese Academy of Sciences (KZCX2-YW-328). We thank all other participating colleagues and students for their dedications to these projects and the data collection campaigns. We also wish to thank W. Wagner and two anonymous reviewers for their constructive comments to the manuscript.

Edited by: P. Oevelen

\section{References}

Albergel, C., Rüdiger, C., Carrer, D., Calvet, J.-C., Fritz, N., Naeimi, V., Bartalis, Z., and Hasenauer, S.: An evaluation of ASCAT surface soil moisture products with in-situ observations in Southwestern France, Hydrol. Earth Syst. Sci., 13, 115-124, doi:10.5194/hess-13-115-2009, 2009.

Balsamo, G., Viterbo, P., Beljaars, A., van den Hurk, B., Hirschi, M., Betts, A. K., Scipal, K.: A revised hydrology for the ECMWF model: Verification from field site to terrestrial water storage and impact in the Integrated Forecast System, ECMWF Tech. Memo., 563, pp. 30, 2008.

Bartalis, Z., Wagner, W., Naeimi, V., Hasenauer, S., Scipal, K., Bonekamp, H., Figa, J., and Anderson, C.: Initial soil moisture retrievals from the METOP-A Advanced Scatterometer (ASCAT), Geophys. Res. Lett., 34, L20401, 1-5, doi:10.1029/2007GL031088, 2007.

Bengtsson, L.: The global atmospheric water cycle, Environ. Res. Lett., 5(2010), 025002, doi:10.1088/1748-9326/5/2/025002, 2010.

Dente, L., Vekerdy, Z., Su, Z., and Wen, J.: Continuous in situ soil moisture measurements at Maqu site. Technical report, EU CEOP AEGIS project, pp. 12, 2009.

Dente, L., Vekerdy, Z., Su, Z., and Wen, J.: Maqu soil moisture monitoring network for validation of satellite products, submitted to to Int. J. App. Earth Obs. and Geoinformation, Special
Issue on Retrieval of Key Eco-hydrological Parameters for Cold and Arid Regions, 2010.

de Rosnay, P., Drusch, M., Boone, A., Balsamo, G., Decharme, B., Harris, P., Kerr, Y., Pellarin, T., Polcher, J., and Wigneron, J.-P.: The AMMA Land Surface Model Intercomparison Experiment coupled to the Community Microwave Emission Model: ALMIP-MEM, ECMWF Tech. Memo., 565, pp. 30., 2008.

Dirmeyer, P. A., Guo, Z. C., and Gao, X.: Comparison, validation, and transferability of eight multiyear global soil wetness products, J. Hydrometeor., 5(6), 1011-1033, 2004.

Dorigo, W. A., Scipal, K., Parinussa, R. M., Liu, Y. Y., Wagner, W., de Jeu, R. A. M., and Naeimi, V.: Error characterisation of global active and passive microwave soil moisture data sets, Hydrol. Earth Syst. Sci. Discuss., 7, 5621-5645, doi:10.5194/hessd7-5621-2010, 2010.

Drusch, M., Holmes, T., de Rosnay, P., Balsamo, G.: Comparing ERA-40 based L-band brightness temperatures with Skylab observations: A calibration/validation study using the Community Microwave Emission Model, ECMWF Tech. Memo., 566, pp. 20, 2008.

Entekhabi, D., Njoku, E. G., O’Neill, P. E., Kellogg, K. H., Crow, W. T., Edelstein, W. N., Entin, J. K., Goodman, S. D., Jackson, T. J., Johnson, J., Kimball, J., Piepmeier, J. R., Koster, R. D., Martin, N., McDonald, K. C., Moghaddam, M., Moran, S., Reichle, R., Shi, J. C., Spencer, M. W., Thurman, S. W., Tsang, L., and Van Zyl, J.: The Soil Moisture Active Passive (SMAP) Mission, Proc. IEEE, 98(5), 704-816, 2010.

ESLs+ARRAY: Release of SMOS level 2 REPROCESSED Soil moisture products, 24 March 2011, available at: http:// calvalportal.ceos.org/cvp/web/guest/smos-calibration, 2011.

Fabbri, A., Fen-Chong, T., and Coussy O.: Dielectric capacity, liquid water content, and pore structure of thawing-freezing materials, Cold Reg. Sci. Technol., 44, 52-66, 2006.

FAO: Digital soil map of the world (DSMW), Tech. Rep., Food and Agriculture Organization of the United Nations, Re-issued version, 2003.

Frison, P. L., Mougin, E., and Hiernaux, P.: Observation and interpretation of seasonal ERS-1 wind scatterometer data over Northern Sahel (Mali), Remote Sens. Environ., 63, 233-242, 1997.

Gruhier, C., de Rosnay, P., Hasenauer, S., Holmes, T., de Jeu, R., Kerr, Y., Mougin, E., Njoku, E., Timouk, F., Wagner, W., and Zribi, M.: Soil moisture active and passive microwave products: intercomparison and evaluation over a Sahelian site, Hydrol. Earth Syst. Sci., 14, 141-156, doi:10.5194/hess-14-1412010, 2010.

Holmes, T. R. H., De Jeu, R. A. M., Owe, M., and Dolman, A. J.: Land Surface Temperature from Ka-band $(37 \mathrm{GHz})$ Passive Microwave Observations, J. Geophys. Res., 114, D04113, doi:10.1029/2008JD010257, 2009.

Jackson, T. J., Vine, D. M. L., Hsu, A. Y., Oldack, A., Starks, P. J., Swift, C. T., Isham, J. D., and Haken, M.: Soil moisture mapping at regional scales using microwave radiometry: The Southern Great Plains hydrology experiment, IEEE T. Geosci. Remote Sens., 37, 2136-2149, 1999.

Kerr, Y., Waldteufel, P., Wigneron, J.P., Martinuzzi, J.M., Font, J., and Berger, M.: Soil moisture retrieval from space: The Soil Moisture and Ocean Salinity (SMOS) mission, IEEE T. Geosci. Remote Sens., 39(8): 1729-1735, 2001.

Liu, Y. Y., Parinussa, R. M., Dorigo, W. A., De Jeu, R. A. M., Wag- 
ner, W., van Dijk, A. I. J. M., McCabe, M. F., and Evans, J. P.: Developing an improved soil moisture dataset by blending passive and active microwave satellite-based retrievals, Hydrol. Earth Syst. Sci., 15, 425-436, doi:10.5194/hess-15-425-2011, 2011.

Ma, Y., Wang, J. M., Huang, R. H., Wei, G., Menenti, M., Su, Z., $\mathrm{Hu}, \mathrm{Z}$. Y., Gao, F., and Wen, J.: Remote sensing parameterization of land surface heat fluxes over arid and semi-arid areas, Adv. Atmosph. Res., 20(4), 530-539, 2003.

Ma, Y., Zhong, L., Su, Z., Ishikawa, H., Menenti, M., and Koike, T.: Determination of regional distributions and seasonal variations of land surface heat fluxes from Landsat-7 Enhanced Thematic Mapper data over the central Tibetan Plateau area, J. Geophys. Res., 111(D10), D10305, doi:10.1029/2005JD006742, 2006.

Ma, Y., Song, M., Ishikawa, H., Yang, K., Koike, T., Jia, L., Menenti, M., and Su, Z.: Estimation of the regional evaporative fraction over the Tibetan Plateau area by using Landsat-7 ETM data and the field observations, J. Meteorol. Soc. Jap., 85A, 295309, 2007.

Meesters, A. G. C. A., De Jeu, R. A. M., and Owe, M.: Analytical Derivation of the Vegetation Optical Depth from the Microwave Polarization Difference Index, IEEE Geosci. Remote Sens. Lett., 2, 121-123, 2005.

Milly, P. C. D. and Dunne, K. A.: Sensitivity of the global water cycle to the water-holding capacity of land, J. Climate, 7, 506526, 1994.

Njoku, E. G., Jackson, T. J., Lakshmi, V., Chan, T. K., and Nghiem, S.V.: Soil moisture retrieval from AMSR-E, IEEE T. Geosci. Remote Sens., 41, 215-229, 2003.

Owe, M., De Jeu, R., and Holmes, T.: Multisensor historical climatology of satellite-derived global land surface moisture, J. Geophys. Res.-Earth Surface, 113, F01002, doi:10.1029/2007JF000769, 2008.

Polcher, J.: Sensitivity of tropical convection to land surface processes, J. Atmos. Sci., 52, 3144-3161, 1995.

Qin, J., Liang, S.-L., Yang, K., Kaihotsu, I., Liu, R.-G., and Koike, T.: Simultaneous estimation of both soil moisture and model parameters using particle filtering method through the assimilation of microwave signal, J. Geophys. Res., 114, D15103, doi:10.1029/2008JD011358, 2009.

Reynolds, C. A., Jackson, T. J., and Rawls, W. J.: Estimating Available Water Content by Linking the FAO Soil Map of the World with Global Soil Profile Databases and Pedo-transfer Functions. Proceedings of the AGU 1999 Spring Conference, Boston, MA. 1 May-4 June, 1999.

Rodell, M., Houser, P. R., Jambor, U., Gottschalck, J., Mitchell, K., Meng, C.-J., Arsenault, K., Cosgrove, B., Radakovich, J., Bosilovich, M., Entin, J. K., Walker, J. P., Lohmann, D., and Toll, D.: The Global Land Data Assimilation System, B. Am. Meteorol. Soc., 85(3), 381-394, , 2004.

Rüdiger, C., Calvet, J.-C., Gruhier, C., Holmes, T., De Jeu, R., and Wagner, W.: An intercomparison of ERS-Scat and AMSR-E soilmoisture observations with model simulations over France, J. Hydrometeorol., 10(2), 431-447, doi:10.1175/2008JHM997.1., 2009.

Scipal, K., Holmes, T., De Jeu, R., Naeimi, V., and Wagner, W.: A possible solution for the problem of estimating the error structure of global soil moisture data sets, Geophys. Res. Lett., 35, L24403, doi:10.1029/2008GL035599, 2008.
Sinclair, S. and Pegram, G. G. S.: A comparison of ASCAT and modelled soil moisture over South Africa, using TOPKAPI in land surface mode, Hydrol. Earth Syst. Sci., 14, 613-626, doi:10.5194/hess-14-613-2010, 2010.

SMOS: SMOS level 2 Processor for Soil Moisture Algorithm Theoretical Basis Document (ATBD), SO-TN-ARR-L2PP-0037, Issue 3.4, Date 24 January 2011, 2011.

Su, Z., Troch, P. A., and De Troch, F. P.: Remote sensing of bare soil moisture using EMAC/ESAR data, Int. J. Remote Sens., 18, 2105-2124, 1997.

Su, Z., Dorigo, W., Fernández-Prieto, D., Van Helvoirt, M., Hungershoefer, K., de Jeu, R., Parinussa, R., Timmermans, J., Roebeling, R., Schröder, M., Schulz, J., Van der Tol, C., Stammes, P., Wagner, W., Wang, L., Wang, P., and Wolters, E.: Earth observation Water Cycle Multi-Mission Observation Strategy (WACMOS), Hydrol. Earth Syst. Sci. Discuss., 7, 7899-7956, doi:10.5194/hessd-7-7899-2010, 2010.

Tian, X.-J., Xie , Z.-H., Dai, A.-G., Shi, C.-X., Jia, B.-H., Chen, F., and Yang, K.: A dual-pass variational data assimilation framework for estimating soil moisture profiles from AMSR-E microwave brightness temperature, J. Geophys. Res., 114, D16102, doi:10.1029/2008JD011600, 2009.

van der Velde, R.: Soil moisture remote sensing using active microwaves and land surface modelling, $\mathrm{PhD}$ thesis, University of Twente, pp. 193, 2010.

van der Velde, R. and Su, Z.: Dynamics in land surface conditions on the Tibetan Plateau observed by ASAR, Hydrolo. Sci. J., 54(6), 1079-1093, 2009.

van der Velde, R., Su, Z., and Ma, Y: Impact of soil moisture dynamics on ASAR signatures and its spatial variability observed over the Tibetan plateau, Sensors, 8(2008), 9, 5479-5491, 2008.

van der Velde, R., Su, Z., Ek, M., Rodell, M., and Ma, Y.: Influence of thermodynamic soil and vegetation parameterizations on the simulation of soil temperature states and surface fluxes by the Noah LSM over a Tibetan plateau site, Hydrol. Earth Syst. Sci., 13, 759-777, doi:10.5194/hess-13-759-2009, 2009.

Wagner, W., Scipal, K., Pathe, C., Gerten, D., Lucht, W., and Rudolf, B.: Evaluation of the agreement between the first global remotely sensed soil moisture data with model and precipitation data, J. Geophys. Res.-Atmos., 108, 4269, doi:10.1029/2002JD002755, 2003.

Wen, J. and Su, Z.: A Method for Estimating Relative Soil Moisture with ESA Wind Scatterometer Data, Geophys. Res. Lett., 30(7), 1397, doi:10.1029/2002GL016557, 2003a.

Wen, J. and Su, Z.: Estimation of soil moisture from ESA Windscatterometer data, Phys. Chem. Earth, 28(1-3), 53-61, 2003 b.

Woodhouse, I. H. and Hoekman, D.H.: Determining Land-surface parameters from the ERS Wind scatterometer, IEEE T. Geosci. Remote Sens., 38, 126-140, 2000.

Yang, K., Watanabe, T., Koike, T., Li, X., Fujii, H., Tamagawa, K., Ma, Y., and Ishikawa, I.: Auto-calibration system developed to assimilate AMSR-E data into a land surface model for estimating soil moisture and the surface energy budget, J. Meteorol. Soc. Japan, 85A, 229-242, 2007.

Yang, K., Koike, T., Kaihotsu, I., and Qin, J.: Validation of a dualpass microwave land data assimilation system for estimating surface soil moisture in semi-arid regions, J. Hydrometeor., 10(3), 780-794, 2009. 